\title{
Condensed Contents
}

\section{Editorial}

1 What is changing and what isn't in The Journal of Thoracic and Cardiovascular Surgery: The cardiovascular and thoracic service-line concept L. H. Cohn

\section{Surgery for Acquired Cardiovascular Disease (ACD)}

3 Custom-tailored valved conduit for complex aortic root disease

G. Krasopoulos, T. E. David, and S. Armstrong

8 Spatiotemporal patterns of smooth muscle cell changes in ascending aortic dilatation with bicuspid and tricuspid aortic valve stenosis: Focus on cell-matrix signaling $\mathcal{B}$

A. Della Corte, C. Quarto, C. Bancone, C. Castaldo,

F. Di Meglio, D. Nurzynska, L. S. De Santo, M. De Feo,

M. Scardone, S. Montagnani, and M. Cotrufo

19 Aortic valve replacement with Toronto SPV bioprosthesis: Optimal patient survival but suboptimal valve durability

T. E. David, C. M. Feindel, J. Bos, J. Ivanov, and

S. Armstrong

25 Less-invasive and highly effective method for preventing methicillin-resistant Staphylococcus aureus graft infection by local sustained release of vancomycin

H. Sakaguchi, A. Marui, K. Hirose, T. Nomura, Y. Arai,

S. C. Bir, Y. Huang, J. Esaki, Y. Tabata, T. Ikeda, and

M. Komeda

32 Sternal microcirculation after skeletonized versus pedicled harvesting of the internal thoracic artery: A randomized study

H. Kamiya, P. Akhyari, A. Martens, M. Karck, A. Haverich, and A. Lichtenberg

\section{General Thoracic Surgery (GTS)}

38 Diaphragmatic hernias after sequential left ventricular assist device explantation and orthotopic heart transplant: Early results of laparoscopic repair with polytetrafluoroethylene S. S. Groth, B. A. Whitson, J. D'Cunha, R. S. Andrade, and M. A. Maddaus

44 Pathologic stage I non-small cell lung cancer with high levels of preoperative serum carcinoembryonic antigen: Clinicopathologic characteristics and prognosis

H. Matsuguma, R. Nakahara, S. Igarashi,

Y. Ishikawa, H. Suzuki, N. Miyazawa, S. Honjo, and $\mathrm{K}$. Yokoi

\section{Surgery for Congenital Heart Disease (CHD)}

50 Consequences of a selective approach toward pulmonary valve replacement in adult patients with tetralogy of Fallot and pulmonary regurgitation

F. J. Meijboom, J. W. Roos-Hesselink, J. S. McGhie,

S. E. C. Spitaels, R. T. van Domburg, L. M. W. J. Utens, M. L. Simoons, and A. J. J. C. Bogers

56 Hemidiaphragm plication after repair of congenital heart defects in children: Quantitative return of diaphragm function over time

C. J. Baker, V. Boulom, B. L. Reemtsen, R. C. Rollins,

V. A. Starnes, and W. J. Wells 
Angular (Gothic) aortic arch leads to enhanced systolic wave reflection, central aortic stiffness, and increased left ventricular mass late after aortic coarctation repair: Evaluation with magnetic resonance flow mapping P. Ou, D. S. Celermajer, O. Raisky, O. Jolivet, F. Buyens, A. Herment, D. Sidi, D. Bonnet, and E. Mousseaux

69 Histopathologic changes in ascending aorta and risk factors related to histopathologic conditions and aortic dilatation in patients with tetralogy of Fallot $\beta$ U. K. Chowdhury, A. K. Mishra, R. Ray, M. Kalaivani, S. M. Reddy, and P. Venugopal

78 The effect of ductal diameter on surgical and medical closure of patent ductus arteriosus in preterm neonates: Size matters

S. Tschuppert, C. Doell, R. Arlettaz-Mieth, O. Baenziger, V. Rousson, C. Balmer, R. Prêtre, and A. Dodge-Khatami

83 The influence of systemic hemodynamics and oxygen transport on cerebral oxygen saturation in neonates after the Norwood procedure $\beta$ J. Li, G. Zhang, H. Holtby, A.-M. Guerguerian, S. Cai,

T. Humpl, C. A. Caldarone, A. N. Redington, and G. S. Van Arsdell

91 Genetic factors are important determinants of neurodevelopmental outcome after repair of tetralogy of Fallot

I. Zeltser, G. P. Jarvik, J. Bernbaum, G. Wernovsky,

A. S. Nord, M. Gerdes, E. Zackai, R. Clancy,

S. C. Nicolson, T. L. Spray, and J. W. Gaynor

$98 \quad \mathrm{~N}$-terminal B-type natriuretic peptide levels in pediatric patients with congestive heart failure undergoing cardiac surgery

R. Walsh, C. Boyer, J. LaCorte, V. Parnell, C. Sison,

D. Chowdhury, and K. Ojamaa
106 Mixed total anomalous pulmonary venous connection: Anatomic variations, surgical approach, techniques, and results $\beta$ U. K. Chowdhury, B. Airan, A. Malhotra, A. K. Bisoi, A. Saxena, S. S. Kothari, M. Kalaivani, and P. Venugopal

\section{Cardiopulmonary Support and Physiology (CSP)}

117 Atorvastatin impairs the myocardial angiogenic response to chronic ischemia in normocholesterolemic swine M. Boodhwani, S. Mieno, J. Feng, N. R. Sodha, R. T. Clements, S.-H. Xu, and F. W. Sellke

123 Cyclosporine A prevents apoptosis-related mitochondrial dysfunction after neonatal cardioplegic arrest $\beta$

N. Oka, L. Wang, W. Mi, W. Zhu, O. Honjo, and C. A. Caldarone

131 Isoprostanes constrict human radial artery by stimulation of thromboxane receptors, $\mathrm{Ca}^{2+}$ release, and RhoA activation

I. Mueed, T. Tazzeo, C. Liu, E. Pertens, Y. Zhang,

I. Cybulski, L. Semelhago, J. Noora, A. Lamy, K. Teoh,

V. Chu, and L. J. Janssen

139 Nonischemic myocardial acidosis adversely affects microvascular and myocardial function and triggers apoptosis during cardioplegia K. R. Khabbaz, J. Feng, M. Boodhwani, R. T. Clements, C. Bianchi, and F. W. Sellke

\section{Cardiothoracic Transplantation (TX)}

147 Predicting survival among high-risk pediatric cardiac transplant recipients: An analysis of the United Network for Organ Sharing database $\theta$ R. R. Davies, M. J. Russo, S. Mital, T. M. Martens, R. S. Sorabella, K. N. Hong, A. C. Gelijns,

A. J. Moskowitz, J. M. Quaegebeur, R. S. Mosca, and J. M. Chen

The Journal of Thoracic and Cardiovascular Surgery (ISSN 0022-5223) is published monthly by Elsevier Inc., 360 Park Avenue South, New York, NY 10010-1710. Business Office: 1600 John F. Kennedy Blvd, Suite 1800, Philadelphia, PA 19103-2899. Editorial Office: 360 Park Avenue South, New York, NY 10010-1710. Customer Service Office: 6277 Sea Harbor Drive, Orlando, FL 32887-4800. Periodicals postage paid at New York, NY and additional mailing offices. POSTMASTER: Send address changes to The Journal of Thoracic and Cardiovascular Surgery, Elsevier Periodicals Customer Service, 6277 Sea Harbor Drive, Orlando, FL 32887-4800. 
156 Additive protection against lung ischemiareperfusion injury by adenosine $A_{2 A}$ receptor activation before procurement and during reperfusion

205 The acute and chronic effects of bullectomy on TI: cordiovascular function at rest and during VIDEO exercise $\bigcirc$

N. Marchetti, K. T. Criner, M. F. Keresztury, S. Furukawa, and G. J. Criner
206 Intrathoracic migration of a breast prosthesis after thoracotomy $\beta$

A. M. Mehta, M. P. L. Bard, A. van Straten,

I. van Beijeren, and H. Rijna

208 Partial lobar torsion secondary to traumatic hemothorax $\beta$

S. Schena, N. K. Veeramachaneni, S. Bhalla,

F. R. Gutierrez, G. A. Patterson, and D. Kreisel

210 What happens after pneumonectomy?

A prospective study using the transpulmonary thermodilution method

F. Leo, M. Tullii, L. Della Grazia, A. Attanasio,

A. Tosoni, G. Manfredi, M. Venturino, and

L. Spaggiari

212 Hernia of Morgagni: Case report

J. M. Huston, H. King, A. Maresh, D. Liska, J. L. Port,

N. K. Altorki, and P. C. Lee

214 Stable partial dehiscence of aortic homograft inserted freehand by using the subcoronary intra-aortic root noncoronary sinus Ross scallop inclusion technique $\beta$

R. Hopkins, H. Gitter, J. Stave, A. Bert, and M. Atalay

216 An alternative approach for chest drainage after cardiac surgery: Redon drains M. Gwozdziewicz, P. Nĕmec, and A. Steriovsky

218 Rupture of fibrous bands associated with aortic root dilatation

M. Yoshikai, H. Ohnishi, H. Fumoto, and T. Yamamoto

220 Extra-anatomic bypass of the superior vena cava after successful stenting for fibrosing mediastinitis $\mathcal{B}$

E. Pompeo, F. Stella, A. Ippoliti, and T. C. Mineo

222 Ventriculoarterial septal defect with separate aortic and pulmonary valves, but common ventriculoarterial junction

V. T. Tsang, N. Kang, I. Sullivan, J. Marek, and R. H. Anderson

223 Papillary muscle realignment for symptomatic left ventricular outflow tract obstruction

R. Bryant, III and N. G. Smedira 
225 Letters to the Editor

\section{Events of Interest}

\section{Announcements}

\section{A, Notices of Correction}

61

34A Reader Services

105 Change of address

202 Interactive eLearning Activities
Full-text online access to The Journal of Thoracic and Cardiovascular Surgery is now available for all print subscribers. See page 116 for details.

The Journal of Thoracic and Cardiovascular Surgery online is sponsored by St. Jude Medical.

\section{Cover Photographs}

Left to right: Intraoperative view in a patient with idiopathic fibrosing mediastinitis, depicts the fibrotic mass encasing the stented superior vena cava and the extra-anatomic politetrafluoroethylene-graft bypass performed distant from the mass, between the left innominate vein and the right atrium (A). Coronal 3D reconstruction of the computed tomographic scan shows the anatomy of the mediastinum, including both the occluded metal stent (left) lying in the superior vena cava, the patent politetrafluoroethylene graft, and normalization of superior-to-inferior vena cava collateral circulation (B). ${ }^{1}$

Eugenio Pompeo, MD

Two extreme geometries of aortic arch shape can be identified after coarctectomy repair. On the left, the Gothic arch is characterized by a triangular shape with an acute angulation at the top of the arch. There is a disproportionate height/width ratio, with a higher height compared to the arch's width. On the right, the Romanesque arch is characterized by a normally and harmoniously smooth-rounded shape. The height is closely equal to the arch's width. ${ }^{2}$

Phalla $\mathrm{Ou}, \mathrm{MD}$

\section{References}

1. Pompeo E, Stella F, Ippoliti A, Mineo TC. Extra-anatomic bypass of the superior vena cava after successful stenting for fibrosing mediastinitis. J Thorac Cardiovasc Surg. 2008; 135:220-1.

2. Ou P, Celermajer DS, Raisky O, Jolivet O, Buyens F, Herment A, Sidi D, Bonnet D, Mousseaux E. Angular (Gothic) aortic arch leads to enhanced systolic wave reflection, central aortic stiffness, and increased left ventricular mass late after aortic coarctation repair: Evaluation with magnetic resonance flow mapping. $J$ Thorac Cardiovasc Surg. 2008;135:62-8. 